\title{
Part-Time Work and Industry Growth
}

\author{
Bruce C. Fallick ${ }^{*}$
}

February 1998

\begin{abstract}
The popular impression that employment in the U.S. has become more part-time in recent years may be driven by a tendency for faster-growing industries to use relatively more part-time work. This paper documents this association for the period 1983-1993, and demonstrates that it is robust to questions about how to measure industry growth and parttime intensity. A similar relationship can be discerned in several other countries. However, judging from data from the 1930s on, the association does not emerge clearly in the United States until the 1980s, suggesting that part-time work and industry growth are not intrinsically related. Moreover, both the relative growth rates and the relative part-time intensities of industries have changed markedly over the post-war period. There is no indication that part-time work in fast-growing industries is more likely to be involuntary, although this may be true for entering workers, nor has there been any trend in that direction.
\end{abstract}

JEL Classification: J29

"Federal Reserve Board, Washington, D.C. 20551. E-mail: bfallick@frb.gov. The views expressed are those of the author and do not necessarily represent those of the Board of Governors or the staff of the Federal Reserve System. 


\section{Introduction}

Headlines such as "Workers Feel the Tension of Trend to Part-Time Jobs" and "Many Workers Frustrated by Lack of Full-Time Jobs" (Behr and Evans 1997) reflect a common concern that a large proportion of the jobs which have been created in the United States in recent years are part-time. This concern may seem misplaced, since the proportion of the U.S. workforce that is working part-time has not increased appreciably since the early 1980s. However, an important part of the story is the perception that much of the hiring done by the fast-growing industries, which, to many, represent the future of our economy, is for part-time positions. There is some basis for this view. The table below ranks nonagricultural industry divisions, from highest to lowest, according to their growth rates of their employment shares (that is, the industry's growth rate minus the aggregate growth rate) between 1983 and 1993, and again by the percent of their workforce who worked part-time, on average, over the same period. ${ }^{1}$

\footnotetext{
${ }^{1}$ See the next section for definitions. The data are drawn from the March Current Population Surveys. The redesign of the CPS in 1994 makes 1993 a natural stopping point for the analysis in this paper, but none of its conclusions appear to be contradicted by experience since 1993. The year 1983 was chosen as a beginning point because it is both similar to 1993 in terms of the cyclical behavior of the unemployment rate, and because the "modern" period in which the proportion of the workforce working part-time was no longer increasing dramatically had clearly begun by then.
} 


\section{TABLE 1}

\section{Industry Divisions by Growth Rate and Part-Time Intensity, 1983-1993}

\section{By Relative Growth Rate}

\begin{tabular}{lr} 
Industry & Rate \\
\hline 1. Services & 1.2 \\
2. T.C.P.U. & 0.4 \\
3. Retail Trade & 0.4 \\
4. F.I.R.E. & 0.4 \\
5. Construction & 0.0 \\
6. Wholesale Trade & -1.3 \\
7. Manufacturing & -1.9 \\
8. Mining & -5.2 \\
-------------------- & 0.0
\end{tabular}

By Proportion Part-time

\begin{tabular}{lc} 
Industry & Proportion \\
\hline 1. Retail Trade & 40.0 \\
2. Services & 30.5 \\
3. Construction & 23.2 \\
4. F.I.R.E. & 17.0 \\
5. T.C.P.U. & 14.0 \\
6. Wholesale Trade & 13.6 \\
7. Manufacturing & 11.3 \\
8. Mining & 10.0 \\
---------------------- & 24.7
\end{tabular}

There has, indeed, been a tendency for industries that are more "intensive" in part-time labor to grow more quickly.

If rapidly growing industries are the main venue for hiring, this does not bode well for people seeking full-time employment, or for those who see their futures in those fast-growing, cutting-edge industries that seem to dominate the headlines. Moreover, my previous research indicated that this penchant for part-timers mostly explains why expanding industries are more likely to hire new entrants to the labor force, presumably at the expense of experienced or displaced workers, than are their slower-growing counterparts (Fallick 1996).

Accordingly, we would like to know how much stock to put in the apparent association between industry growth and part-time intensity. This paper asks three basic questions: 1)How robust is the correlation between alternative measures of growth and "part-time-ness"? 2)Should we expect the relationship to continue to hold as time goes on? That is, is part-time labor a natural complement to rapid growth, or an intrinsic characteristic of certain industries that happen to have grown quickly of late? 3)Do rapidly growing industries provide opportunities for people seeking part-time employment, or are people who prefer full-time work constrained to take part-time jobs because rapidly-growing industries are where the jobs are? 


\section{Measures}

Define the relative growth rate of an industry as the rate of growth of its share in total employment, and its part-time intensity as the percentage of its workforce that works part-time. Both concepts -- industry employment and part-time -- work require some clarification. My data are drawn from the regular part of the March Current Population Surveys, so each observation is associated with the industry of the person's main job during the reference week. ${ }^{2}$ The proportion part-time is defined as the ratio of the number of persons who worked between 1 and 34 hours (at all jobs combined) during the reference week to the number of persons who worked at least 1 hour during the reference week. This definition was chosen for historical comparability, but the results here (and below, where relevant) would be at least as strong if usual weekly hours were used to define part-time. ${ }^{3}$ Note also that while one would like a measure of full-time and part-time jobs, until 1994 the CPS provided only a measure of full-time and part-time workers. Consequently, these data cannot be used to measure the number of people who work "full-time" by working at more than one part-time job.

Using these definitions, Figure 1 shows the association between the rate of growth and the part-time intensity of industries. The figure plots the part-time intensity and relative growth rate, over the period 1983-1993, of industries defined at the 2-digit level. ${ }^{4}$ More formally, the top panel of table 2 shows the correlation coefficients between relative employment growth rates and part-time intensity, for both the 2-digit industries used in figure 1 and the industry divisions in table 1. The first column shows the unweighted (Pearson) correlation coefficients, the second shows the correlations weighted by the average share of employment in the industry, and the third row shows the Spearman rank correlations. (Significance levels appear in parentheses.)

\footnotetext{
${ }^{2}$ Observations were weighted by the CPS person-weights when calculating growth rates and part-time intensities. Only observations employed during the reference week were used when calculating growth rates.

${ }^{3}$ Over the 1983-1993 periods, 25 percent of observations worked part-time last week, compared to only 19 percent who reported that they usually worked part-time. However, the correlation between the two (at the 2-digit industry level) is 0.99 .

${ }^{4}$ The 3-digit Census industry codes from the CPS were mapped, to the best of my ability, into 2-digit 1987 SIC codes. I excluded government, agriculture, forestry, and fisheries from the analysis.
} 
TABLE 2

Correlations between Growth Rates and Part-Time Intensity, 1983-1993

\begin{tabular}{|c|c|c|c|c|}
\hline Aggregation & $\mathbf{N}$ & (1) & (2) & (3) \\
\hline & & Unweighted & Weighted & Rank \\
\hline \multicolumn{5}{|c|}{ Employment Growth Rate and Part-Time Employment } \\
\hline Division & 8 & $\begin{array}{c}0.61 \\
(0.11)\end{array}$ & $\begin{array}{c}0.71 \\
(0.05)\end{array}$ & $\begin{array}{c}0.79 \\
(0.02)\end{array}$ \\
\hline 2-digit SIC & 61 & $\begin{array}{c}0.32 \\
(0.01)\end{array}$ & $\begin{array}{c}0.36 \\
(0.00)\end{array}$ & $\begin{array}{c}0.50 \\
(0.00)\end{array}$ \\
\hline \multicolumn{5}{|c|}{ Accession Rate and Part-Time Accessions } \\
\hline Division & 8 & $\begin{array}{c}0.39 \\
(0.35)\end{array}$ & $\begin{array}{c}0.51 \\
(0.20)\end{array}$ & $\begin{array}{c}0.52 \\
(0.18)\end{array}$ \\
\hline 2-digit SIC & 61 & $\begin{array}{c}0.72 \\
(0.00)\end{array}$ & $\begin{array}{c}0.42 \\
(0.00)\end{array}$ & $\begin{array}{c}0.69 \\
(0.00)\end{array}$ \\
\hline \multicolumn{5}{|c|}{ Hours Growth Rate and Part-Time Hours } \\
\hline Division & 8 & $\begin{array}{c}0.61 \\
(0.11)\end{array}$ & $\begin{array}{c}0.70 \\
(0.05)\end{array}$ & $\begin{array}{c}0.88 \\
(0.00)\end{array}$ \\
\hline 2-digit SIC & 61 & $\begin{array}{c}0.31 \\
(0.01)\end{array}$ & $\begin{array}{c}0.37 \\
(0.00)\end{array}$ & $\begin{array}{c}0.47 \\
(0.00)\end{array}$ \\
\hline \multicolumn{5}{|c|}{ Earnings Growth Rate and Part-Time Earnings } \\
\hline Division & 8 & $\begin{array}{c}0.67 \\
(0.06)\end{array}$ & $\begin{array}{c}0.80 \\
(0.02)\end{array}$ & $\begin{array}{c}0.74 \\
(0.04)\end{array}$ \\
\hline 2-digit SIC & 61 & $\begin{array}{c}0.31 \\
(0.02)\end{array}$ & $\begin{array}{c}0.38 \\
(0.00)\end{array}$ & $\begin{array}{c}0.50 \\
(0.00)\end{array}$ \\
\hline
\end{tabular}

The positive association between employment growth and part-time intensity over this recent period is clear. However, questions arise as to whether the rate of growth of total industry employment and the percentage of an industry's total workforce that is part-time are the correct measures to use. If we are concerned about the preponderance of part-time employment in job creation -- that the opportunities available to job-seekers these days consist 
largely of part-time positions -- then we may be more interested in the relationship between the flow of new jobs and part-time intensity. That is, the percentage of industry accessions who are part-time tells us more about the prospects for job seekers from outside of the industry. Similarly, if heavy use of part-time is an intrinsic feature of industry growth, rather than a feature of the industry itself, then we may be more interested in the degree to which that growth is manifested in part-time labor. ${ }^{5}$

I classify an individual in the March CPS as an accession into an industry if she is employed in that industry according to the regular part of the survey, and was not employed in that industry in the previous year, according to the March supplement, either because she was not employed in the previous year or because she was employed in a different industry (on her main job) in the previous year . ${ }^{6}$ The second panel of table 2 replicates the first, but replaces the fraction of an industry's employment that works part-time with the fraction of the accessions into the industry that work part-time, and replaces the industry growth rates with industry accession rates, defined as the number of accessions into the industry in a year divided by total employment in the industry in that year. The correlation between industry growth and part-time intensity is stronger, at the 2-digit level of aggregation, when only accessions, rather than the total workforce, are considered.

For similar reasons, one may be interested in whether entry-level jobs in faster-growing industries tend to be more heavily part-time, that is, whether people beginning their careers in one of the faster-growing industries are faced with a greater chance of working part-time. Given the information available, a reasonable way to address this question is to examine the correlations by age group. As it happens, the correlations are quite similar across age groups. (Results not shown.) The association between industry growth and part-time intensity is just as marked for older workers as for younger workers.

A second issue with the measures used in table 1 and the top of table 2 is that both the growth in industry employment and the industry's part-time intensity, as calculated there,

\footnotetext{
${ }^{5}$ On the other hand, accession rates may confuse industry growth with industry turnover.

${ }^{6}$ There is significant room for misclassification of a person's industry in the CPS, and for misclassifying a worker as a new hire. See Fallick (1996) for more discussion.
} 
treat part-time and full-time workers equally: Each counts as one full observation. But the evident importance of part-time versus full-time work itself suggests that total employment may not be the appropriate measure of industry size, since a given increase in the number of part-time workers represents a smaller increase in hours, and presumably output, than an identical increase in the number of full-time workers. In other words, might it be that part-time intensive industries appear to grow faster simply because, by virtue of hiring more part-timers, they have to hire more of them to increase hours by any given amount? The correlations in the third panel of table 2 weight each part-time/full-time worker by the average hours per week worked by part-time/full-time workers in his industry-year cell. Thus, the growth rate of an industry is the growth rate of its hours worked, and its part-time intensity refers to the fraction of total hours that are worked by part-time workers. ${ }^{7}$ This change in measurement makes little difference to the estimates.

Additionally, since part-timers are generally paid at a lower hourly rate than full-timers, than one may infer, arguably, that their productivity is lower, and therefore that one hour of part-time labor should not be counted as equal to one hour of full-time labor. If the relative prices of various "grades" of labor have remained constant over the years and across industries (an admittedly strong assumption), then substituting compensation for employment or hours is one way to control for differences in productivity between part-time and full-time labor. Given the limitations of the CPS data, I used weekly earnings rather than total compensation. ${ }^{8}$ The results, shown in the bottom panel of table 2 , are similar to those in the previous panel. ${ }^{9}$

\footnotetext{
${ }^{7}$ This is not strictly true because, as noted above, the weekly hours measure refers to the hours worked by a person at all jobs.

${ }^{8}$ The mean weekly earnings for the Outgoing Rotation Group in each industry-year-part-time/full-time cell were applied to the full sample in that cell.

${ }^{9}$ In a related vein, only a small part of the correlation between part-time work and industry growth can be accounted for by the age, gender, race and educational distribution of the workforce. While it is true that fastergrowing industries tend to employ and to hire more young, old, and highly educated workers, this does not explain their heavy use of part-time labor.
} 


\section{Intrinsic or Coincidence?}

The previous section demonstrates that the recent positive association between an industry's growth rate and the percentage of that industry's work force who work part-time stands up to alterations in the definitions and measurement of industry growth and of part-time employment. What is behind it? Is greater use of part-time work an intrinsic characteristic of fast growth? Or do those industries that happen to have grown relatively quickly in the 1980s and early 1990s tend, by their nature, to use more part-time work whether growing fast or not?

Recent rapid growth appears to have been associated with part-time work in countries other than the United States, as well. Table 3 displays correlations between industry growth rates and part-time intensities in data for several countries drawn from the Luxembourg Income Study. ${ }^{10}$ The countries, time periods, and industry definitions used were determined by the availability of data.. ${ }^{11}$ In all cases, government and agriculture were excluded from the analysis. In no case would there inclusion have weakened the results.

Although the results are by no means uniform, the comparison across countries indicates that there may be more to this matter than mere happenstance in the United States. In those countries that one may argue are most like the U.S. (Australia, Canada, the Netherlands, Sweden, and the United Kingdom), the correlations are significantly positive in three of five cases, and the results for the other two are suggestive.

\footnotetext{
${ }^{10}$ Material from the Family Expenditure Survey (United Kingdom) is Crown Copyright; has been made available by the office for National Statistics through the ESRC Data Archive; and has been used by permission. Neither the Office for National Statistics nor the ESRC Data Archive bear any responsibility for the analysis or the interpretation of the data reported here.

${ }^{11}$ The table reports correlations for every country participating in the LIS for which sufficient person-level data were available, with the exception of Germany. Due to re-unification, consistent data for Germany do not span a sufficiently long period to be comparable to the other countries.
} 
TABLE 3

Correlations between Employment Growth and Part-Time Intensity, LIS

\begin{tabular}{|c|c|c|c|c|c|}
\hline Country & Years & $\mathbf{N}$ & $\mathbf{( 1 )}$ & $\mathbf{( 2 )}$ & $\mathbf{( 3 )}$ \\
\hline & & & Unweighted & Weighted & Rank \\
\hline & & & 0.74 & 0.58 & 0.82 \\
Australia & $1981-1989$ & 10 & $(0.01)$ & $(0.08)$ & $(0.01)$ \\
\hline & & & 0.27 & 0.27 & 0.50 \\
Canada & $1987-1994$ & 12 & $(0.40)$ & $(0.39)$ & $(0.10)$ \\
\hline & & & 0.40 & 0.36 & 0.43 \\
Israel & $1979-1992$ & 6 & $(0.43)$ & $(0.49)$ & $(0.40)$ \\
\hline & & & 0.87 & 0.91 & 0.67 \\
Netherlands & $1983-1991$ & 8 & $(0.01)$ & $(0.01)$ & $(0.07)$ \\
\hline & & & 0.47 & 0.43 & 0.39 \\
Sweden & $1981-1992$ & 25 & $(0.02)$ & $(0.03)$ & $(0.05)$ \\
\hline Taiwan & $1981-1991$ & 8 & $(0.60)$ & $(0.60)$ & $(0.65)$ \\
\hline United & & & 0.18 & 0.25 & 0.34 \\
Kingdom & $1979-1986$ & 28 & $(0.35)$ & $(0.20)$ & $(0.08)$ \\
\hline
\end{tabular}

Fast growth itself could call for intensive use of part-time workers if, for example, fast growth requires greater flexibility in adjusting one's workforce, or involves lots of temporary tasks that part-timers are better suited or more willing to perform (E.g., Friesen 1997). ${ }^{12}$ If so, then we might expect faster industry growth to have been associated with more part-time labor in past periods as well, and would expect it to be so in the future. On the other hand, if it is only a matter of the particular industries that happen to have been growing quickly recently, then we have no obvious cause to think that this problem, if problem it be, will stay

\footnotetext{
${ }^{12}$ One consideration is that there may not be as much room to adjust the hours of full-time employees upward as downward, whereas part-time employees may be more equally flexible in both directions. However, one must be careful not to confuse part-time with contingent work.
} 
with us over the long run.

Some light may be shed on this question by examining the relationship between industry growth and part-time work in earlier periods. The earliest year in which the decennial Census included data on the distribution of weekly hours worked by industry was 1940 , so the decade of the 1940s is as far back as national household survey data allow us to go. Unfortunately, unlike the more recent CPS data, the 1940 and 1950 Censuses asked only for the number of hours that a person worked last week, with no information on the number of hours usually worked. Using this number to define part-time versus full-time work likely overstates the incidence of part-time work because short weeks due, for example, to illness or temporary downturns in production will be counted.

In order to facilitate comparisons with the 1940s, tables 1 and 2 above used hours actually worked during the reference week. For that more recent period, using usual hours instead of last week's hours would have made little difference (the results were a bit stronger using usual hours), and we can hope that actual hours create no problems for the 1940s either. $^{13}$

The industry classification schemes differ between the two periods, and are not compatible. For the more recent period, the same 2-digit coding as above is used. For the 1940 and 1950 Censuses, industries were aggregated into a different "2-digit" scheme comprising 99 industries.

Table 4 displays the correlations between industry growth rates and the fraction of employment that is part-time for the period 1940 to 1950 , once using part-time intensities in 1940 and once using part-time intensities in 1950. In contrast to the more recent period, the correlations in table 4 are negative. Nor was the 1940s simply an odd time. The correlation becomes progressively more positive as the decade examined approaches the 1980s (results not shown). There is no evidence here that greater use of part-time work is an intrinsic characteristic of relatively fast growth, in the sense that the positive relationship held true in

\footnotetext{
${ }^{13}$ Note also that the results (for either period) are not sensitive to whether one uses the standard definition of part-time as less than 35 hours per week or another conventional cut-off such as 40 hours per week.
} 
all decades. Indeed, an observer in 1950 may have been tempted to conclude that the relationship was negative.

TABLE 4

Correlations between Hours Growth Rate and Part-Time Intensity, 1940-1950

\begin{tabular}{|c|c|c|c|c|}
\hline \multirow{2}{*}{ Base Year } & $\mathbf{N}$ & $\mathbf{( 1 )}$ & $\mathbf{( 2 )}$ & $\mathbf{( 3 )}$ \\
\hline \multirow{2}{*}{1940} & & Unweighted & Weighted & Rank \\
& 99 & -0.20 & -0.17 & -0.21 \\
& & $(0.05)$ & $(0.10)$ & $(0.04)$ \\
\hline \multirow{2}{*}{1950} & 99 & -0.17 & -0.25 & -0.20 \\
& & $(0.10)$ & $(0.02)$ & $(0.05)$ \\
\hline
\end{tabular}

So, in recent years part-time intensive industries tended to grow relatively quickly, while in the 1940s part-time intensive industries tended to grow relatively slowly. Were these the same industries? No. By these measures, it is not the case that the same industries tended to use more part-time work over the decades. This is illustrated in Table 5, which presents the rankings of the eight nonagricultural industry divisions by their growth rates and fraction part-time in each period. Mining is the most striking case. It is the slowest-growing sector in both sets of data, but is the least part-time intensive in the 1983-93 period while the most part-time intensive in 1940 and $1950 .{ }^{14}$ Wholesale trade also refuses to fit a pattern, while manufacturing, for example, did become less part-time while becoming slower-growing.

\footnotetext{
${ }^{14}$ By the 1960 Census, mining had fallen to the middle of the pack, and by the 1970 Census, mining was the least part-time intensive of the 8 sectors.
} 
TABLE 5

\title{
Rankings of Industry Divisions
}

\author{
In Descending Order of Growth Rate
}

$\begin{array}{ll}\frac{1983-1993 \text { CPS }}{\text { 1. Services }} & \text { 1940-1950 Census } \\ \text { 2. T.C.P.U. } & \text { 2. Whstruction } \\ \text { 3. Retail Trade } & \text { 3. Manufacturing } \\ \text { 4. F.I.R.E. } & \text { 4. T.C.P.U. } \\ \text { 5. Construction } & \text { 5. Retail Trade } \\ \text { 6. Wholesale Trade } & \text { 6. Services } \\ \text { 7. Manufacturing } & \text { 7. F.I.R.E. } \\ \text { 8. Mining } & \text { 8. Mining }\end{array}$

In Descending Order of \% Part-Time

\begin{tabular}{lll}
$\frac{1983-1993 \mathrm{CPS}}{1 .}$ & $\underline{1940 \text { Census }}$ & $\underline{1950 \text { Census }}$ \\
\cline { 2 - 3 } 2. Setail Trade & 2. Coning & 1. Mining \\
3. Construction & 3. Manufaction & 2. Construction \\
4. F.I.R.E. & 4. Services & 3. Services \\
5. T.C.P.U. & 5. Retail Trade & 4. Retail Trade \\
6. Wholesale Trade & 6. T.C.P.U. & 5. Manufacturing \\
7. Manufacturing & 7. F.I.R.E. & 6. F.I.R.E. \\
8. Mining & 8. Wholesale Trade & 7. Wholesale Trade \\
& & 8. T.C.P.U.
\end{tabular}

To push the investigation back another decade, one must turn to other sources of data on the fraction part-time. The National Income and Product Accounts report both total employment and a measure of full-time-equivalent (FTE) employment going back to $1929 .{ }^{15}$ Using the NIPA. data we can define $\mathrm{z}=1-(\mathrm{FTE} / \mathrm{employment})$. If we let $\mathrm{p}=$ the true fraction part-time in an industry and $\alpha=$ the ratio of part-time to full-time average hours in the industry, then $\mathrm{z}=(1-\alpha) \mathrm{p}$. So, if $\alpha$ is fairly constant across industries, then $\mathrm{z}$ is a reasonable proxy for the relative fraction part-time in an industry at any given time.

${ }^{15}$ FTE were calculated by dividing total hours from establishment survey data by estimates of full-time hours. Unfortunately, the source data are lost to posterity. 
Table 6 displays the correlations between 1-(FTE/employment) and the industry growth rate for various periods. ${ }^{16}$ The NIPA data are reported at a somewhat more aggregate level than the "2-digit" scheme used for the 1940 Census data, resulting in 59 industry categories for years between 1929 and 1947 and 60 industries for later years.

\section{TABLE 6}

Correlations between Employment Growth Rate and 1-(FTE/Employment)

\begin{tabular}{|c|c|c|c|c|}
\hline Years & $\mathbf{N}$ & $\mathbf{( 1 )}$ & $\mathbf{( 2 )}$ & $\mathbf{( 3 )}$ \\
\hline & & Unweighted & Weighted & Rank \\
\hline \multirow{2}{*}{$1929-1938$} & 59 & $\begin{array}{c}-0.03 \\
(0.84)\end{array}$ & $\begin{array}{c}0.07 \\
(0.60)\end{array}$ & $\begin{array}{c}-0.01 \\
(0.96)\end{array}$ \\
\hline \multirow{2}{*}{$1939-1947$} & 59 & 0.20 & 0.43 & 0.17 \\
& & $(0.13)$ & $(0.01)$ & $(0.20)$ \\
\hline \multirow{2}{*}{$1948-1958$} & 60 & 0.14 & 0.18 & 0.27 \\
& & $(0.28)$ & $(0.17)$ & $(0.04)$ \\
\hline $1959-1969$ & 60 & 0.06 & -0.10 & 0.31 \\
& & $(0.64)$ & $(0.44)$ & $(0.02)$ \\
\hline $1970-1980$ & 60 & 0.01 & 0.11 & 0.34 \\
& & $(0.95)$ & $(0.40)$ & $(0.01)$ \\
\hline $1981-1991$ & \multirow{2}{*}{60} & 0.27 & 0.31 & 0.55 \\
& & $(0.04)$ & $(0.02)$ & $(0.01)$ \\
\hline
\end{tabular}

The rank correlations are significantly positive throughout the postwar period, but the ordinary correlations vary substantially and a clearly positive association emerges only in the

\footnotetext{
${ }^{16}$ Computing growth rates using FTE instead of employment would be analogous to weighting employment by hours, as in section II. Employment growth rates and FTE growth rates are very similar (with correlations of greater than 0.99 ), so either growth measure would give the same answers.
} 
1980s. ${ }^{17}$ In contrast to the Census data, the rank correlations here may encourage one to suspect that fast growth and intensive use of part-time labor do go together in general, at least in the United States's post-war economy, but the evidence is not compelling.

\section{Voluntary and Involuntary Part-Time}

One would only be concerned about the relative prevalence of part-time jobs in fast-growing industries if many of the people who fill these jobs would rather work full-time. In the economy as a whole, the proportion of the labor force that is working part-time has not increased since about 1983 (following a period of rapid increase in the 1960s and 1970s). Nor has the proportion of those working part-time who are doing so because they could not find full-time work increased since about the same time (again following a period of marked increase). But is this true for people taking jobs in the relatively fast-growing industries?

Classify all people who report that they usually work full-time as full-time workers. Then define a person as an involuntarily part-time worker if he usually works part-time because he cannot find full-time work, and as a voluntarily part-time worker if he usually works part-time for other reasons. ${ }^{18}$ The two questions to be answered are whether relatively fast-growing industries employ and hire a greater proportion of involuntarily part-time workers, and whether these proportions have changed over the period under study.

Figure 2 addresses these questions. It shows the ratio of involuntarily part-time to all usually part-time workers in those 2-digit nonagricultural industries in each quartile of industry growth rates. There is no indication, either in the figure or in more formal correlations shown in the first row of table 7, that a higher proportion of faster-growing

\footnotetext{
${ }^{17}$ Note that the correlations between the growth rate based upon total employment, which is used here, and the rate based upon FTE are not as high for these two earlier decades (approximately 0.94) as they are for the later years (all appr. 0.99). The results for 1939-47 would be weaker if the FTE growth rates were used instead.

${ }^{18}$ Note that this definition differs from the Bureau of Labor Statistics' classifications of involuntary (really "part-time for economic reasons") and voluntary (really "part-time for noneconomic reasons"), which include many people who usually work full-time but worked fewer than 35 hours during the reference week, and include as voluntary those who usually work part-time if the reason given is slack work, material shortages, repairs to plant or equipment, and start or termination of a job during the week.
} 
industries' part-timers are involuntarily part-time, nor that the proportion of part-timers who are involuntary increased for faster-growing industries.

More of a case can be made that involuntary part-time work may be related to relatively rapid growth at the entry level. The third and fourth rows of table 7 uses the industries' accession rates instead of employment growth rates. The remaining rows use employment growth rates, but confine the sample to younger workers. The correlations indicate that industries with higher accession rates have tended to hire a greater proportion of involuntary part-timers among those that they hire to work part-time workforces, and that industries with higher growth rates in an age group likely to be associated with entry-level career-track jobs have tended to employ a greater proportion of involuntary part-timers among the part-timers in that age group. However, these correlations have proven to be more sensitive to changes in the definition of the sample than one would like, so I hesitate to draw strong inferences from them. 
TABLE 7

Growth Rates and Involuntary Part-Time/Total Part-Time

(Two-Digit Industry Level)

\begin{tabular}{|c|c|c|c|c|c|}
\hline Growth & Ages & $\begin{array}{c}\text { Part-Time } \\
\text { Variable }\end{array}$ & (1) & (2) & (3) \\
\hline & & & Unweighted & Weighted & Rank \\
\hline $\begin{array}{c}\text { Employment } \\
\text { Growth } \\
\text { Rate }\end{array}$ & $16+$ & Ratio & $\begin{array}{c}0.01 \\
(0.93)\end{array}$ & $\begin{array}{r}0.00 \\
(0.97)\end{array}$ & $\begin{array}{c}0.02 \\
(0.88)\end{array}$ \\
\hline $\begin{array}{c}\text { Employment } \\
\text { Growth } \\
\text { Rate }\end{array}$ & $16+$ & $\begin{array}{c}\text { Change in } \\
\text { Ratio }\end{array}$ & $\begin{array}{c}0.09 \\
(0.47)\end{array}$ & $\begin{array}{l}-0.06 \\
(0.64)\end{array}$ & $\begin{array}{l}-0.04 \\
(0.77)\end{array}$ \\
\hline $\begin{array}{c}\text { New Hire } \\
\text { Rate }\end{array}$ & $16+$ & Ratio & $\begin{array}{c}0.22 \\
(0.08)\end{array}$ & $\begin{array}{c}0.22 \\
(0.09)\end{array}$ & $\begin{array}{c}0.25 \\
(0.05)\end{array}$ \\
\hline $\begin{array}{c}\text { New Hire } \\
\text { Rate }\end{array}$ & $16+$ & $\begin{array}{c}\text { Change in } \\
\text { Ratio }\end{array}$ & $\begin{array}{c}0.00 \\
(0.98)\end{array}$ & $\begin{array}{c}0.04 \\
(0.76)\end{array}$ & $\begin{array}{r}0.15 \\
(0.29)\end{array}$ \\
\hline $\begin{array}{c}\text { Employment } \\
\text { Growth } \\
\text { Rate }\end{array}$ & $20-24$ & Ratio & $\begin{array}{c}0.10 \\
(0.46)\end{array}$ & $\begin{array}{c}0.17 \\
(0.18)\end{array}$ & $\begin{array}{c}0.17 \\
(0.20)\end{array}$ \\
\hline $\begin{array}{c}\text { Employment } \\
\text { Growth } \\
\text { Rate }\end{array}$ & $20-24$ & $\begin{array}{c}\text { Change in } \\
\text { Ratio }\end{array}$ & $\begin{array}{l}-0.16 \\
(0.27)\end{array}$ & $\begin{array}{l}-0.26 \\
(0.07)\end{array}$ & $\begin{array}{l}-0.20 \\
(0.16)\end{array}$ \\
\hline $\begin{array}{c}\text { Employment } \\
\text { Growth } \\
\text { Rate }\end{array}$ & $25-34$ & Ratio & $\begin{array}{c}0.26 \\
(0.04)\end{array}$ & $\begin{array}{c}0.27 \\
(0.04)\end{array}$ & $\begin{array}{c}0.28 \\
(0.03)\end{array}$ \\
\hline $\begin{array}{c}\text { Employment } \\
\text { Growth } \\
\text { Rate }\end{array}$ & $25-34$ & $\begin{array}{c}\text { Change in } \\
\text { Ratio }\end{array}$ & $\begin{array}{l}-0.05 \\
(0.74)\end{array}$ & $\begin{array}{l}-0.21 \\
(0.13)\end{array}$ & $\begin{array}{l}-0.08 \\
(0.55)\end{array}$ \\
\hline
\end{tabular}




\section{Conclusion}

Popular observers look to visibly fast-growing service and retail industries -transportation, business services, recreation, health care, and the like -- to gauge the opportunities available to people looking for jobs. Seeing how heavily those industries make use of part-time workers, many observers have become concerned that full-time jobs have become increasingly hard to come by. This despite the fact that the percentage of the labor force that works part-time has not changed appreciably since the late 1970s. While the fact that available measures of the number of part-time workers may miss something that is going on with part-time jobs, the impression of an ever-more part-time economy is probably largely driven by the fact that, over the past couple of decades, employment growth has, indeed, been concentrated in industries where part-time work is relatively common.

This paper has documented the positive association between the growth rate of an industry and the proportion of its workforce who work part-time for a period between the early 1980s and the early 1990s, demonstrated that it holds up to questions about the way in which industry growth and part-time intensity are measured, and investigated two aspects of the nature of the relationship.

First, one may conjecture that the part-time labor is particularly well-suited to the changing demands of rapidly growing industries. However, the positive association between industry growth and part-time intensity does not emerge clearly in the data until the 1980s. Moreover, both the relative growth rates and the relative part-time intensities of industries have changed markedly over the post-war period. One should be cautious in assuming that fast-growing industries will continue to use part-time labor intensively, or that part-time 
intensive industries will continue to grow quickly.

Second, there is no indication that the part-time workers at fast-growing industries are more likely to be working part-time because they could not find full-time work. While there is some weak evidence that new or younger workers are more constrained in this fashion, the percentage of involuntary (in the above sense) part-timers among all part-timers in faster-growing industries is neither systematically different than in slower-growing industries, nor does there appear to be any trend in that direction. 


\section{REFERENCES}

Behr, Peter and Judith Evans, "Workers Feel the Tensions of Trend to Part-Time Jobs," The Washington Post, August 7, 1997, p. E1.

Fallick, Bruce C., "The Hiring of New Labor by Expanding Industries," Labour Economics 3(1), March 1996, pp.25 42.

Friesen, Jane, "The Dynamic Demand for Part-time and Full-time Labour," Economica 64(255), August 1997, pp.495-507

Nardonne, Thomas, "Part-Time Employment: Reasons, Demographics, and Trends," Journal of Labor Research 16(3), Summer 1995, pp.275-292.

Tilly, Chris, "Reasons for the Continuing Growth of Part-Time Employment," Monthly Labor Review 114(3), March 1991, pp.10-18.

Zeytinoglu, I.V., "Reasons for Hiring Part-Time Workers," Industrial Relations 31(3), Fall 1992, pp.489-99. 


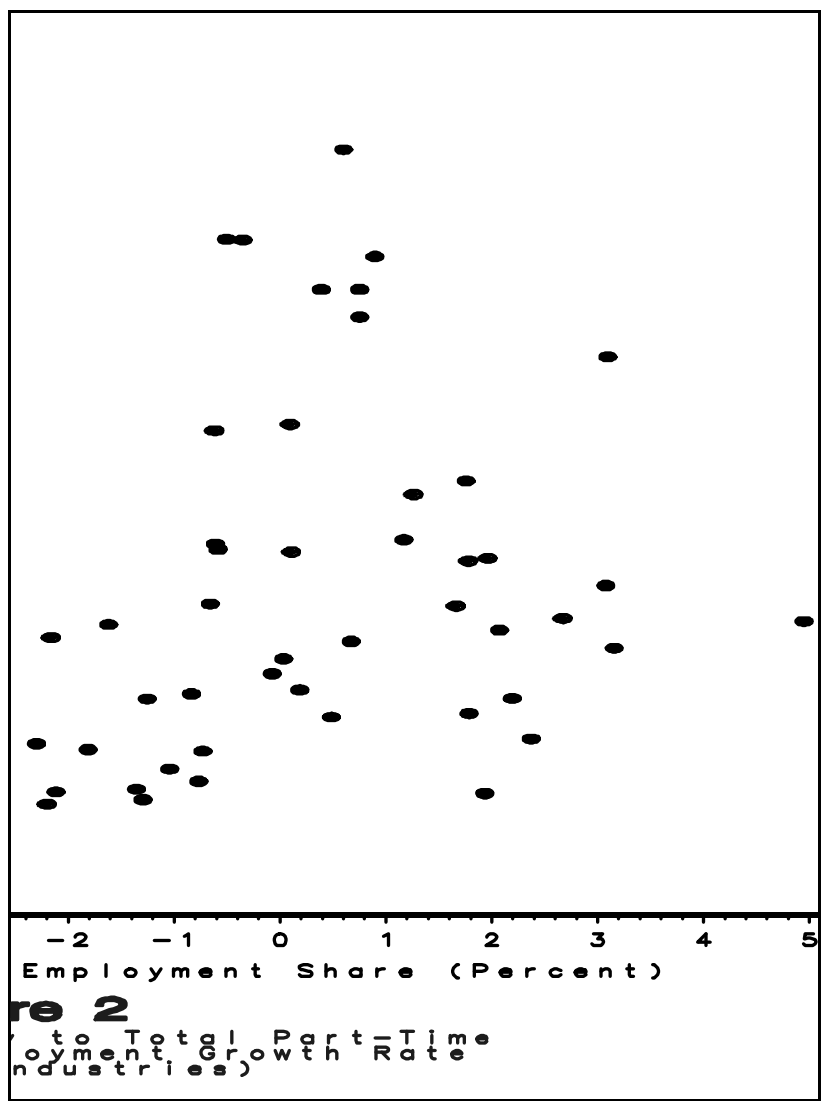

